\title{
Um artefato de defesa em colônias de Meliponíneos
}

\author{
V. de Portugal-Araújo \\ Instituto Nacional de Pesquisas
}

da Amazónia, Manaus

Um dos pormenores de importância no estabelecimento e sobrevivência de colônias de meliponíneos, em ocos de árvores, termiteiras ocupadas ou abandonadas, colmeias ou quaisquer outros lugares de nidificação, é o que diz respeito à arquitetatura das entradas de acesso e comunicação com o exterior.

A despeito de se encontrarem espécies de meliponíneos que apresentam grandes entradas, dando acesso a galerias ou túneis, cuja defesa está a cargo de um grande número de abelhas, é comum verificarem-se entradas de pequeno diâmetro dando passagem a uma, a duas ou três abelhas simultaneamente. As grandes entradas pertencem, geralmente, a grandes colônias de trigonas, quase sempre agressivas, enquanto que as pequenas entradas são comuns a colônias de melíponas.
O número de abelhas guardas é proporcional ao diâmetro das entradas, variando a sua defesa, segundo a espécie, desde o ataque ao inimigo, até à obstrução da entrada com o corpo das guardas e à utilização de artefatos de obstruçẫo ou à utilizaçăo de gomas repelentes e ainda de mimetismo. A obstrução parcial ou total, por meio de gomas, pode ser utilizada durante o dia, mas faz parte do tipo de defesa noturna de várias espécies. A obstrução da entrada com o corpo das abelhas. formando uma barreira, foi observada, pelo autor, em Angola, como defesa ao ataque das formigas carnivoras Dorylus spp. a colmeias povoadas por abelhas Apis mellifera adansonii Lat. A obstrução, em abelhas sem ferrão, com o corpo das guardas, foi observada pelo autor em Melipona rufiventris cf. paraensis 
Ducke e Melipona interrupta Lat. A obstruçăo por meio de um artefato foi agora observada pelo autor em Melipona rufiventris cf. paraensis Ducke.

Suspeita-se que a obstrução corporal ou por meio de um artefato em Melipona rufiventris cf. paraensis, é utilizada, segundo a necessidade de obstrução imediata. A obstruçâo corporal tem sido observada, nesta espécie, por ocasiāo de tentativas de assaltos por abelhas de outras colônias ou engano generalizado, cie localizaçăo de entrada ou entradas. A obstrução por meio de um artefato. foi observada, como defesa ao ataque das abelhas ladras Lestrimelitta limao F. Smith.

A existência de pequenas bolas de própolis pétreo em Melipona rufiventris cf. paraensis, de três a sete milimetros de diâmetro, em número de dez a vinte, localizadas e armazenadas sobre o tampão inferior das colônias ou sobre o ventilador inferior de colmeias experimentais (Portugal Araújo e INPA), fazendo parte, por vezes, como reforço dos tampões, vinha sendo observada pelo autor. Estas pequenas bolas encontram-se levemente soldadas às paredes dos tampōes, ou soltas. O mesmo ocorre em Melipona seminigra merrillae Cock., em cujas colônias se observam bolas de própolis pétreo de sete a quinze milimetros de diâmetro, em número que chega a atingir 100 , em velhas caixas povoadas, e Melipona crinita Moure \& Kerr, onde se verificam bolas de oito a dez milimetros, em número de vinte a trinta, porém não apenas na parte interna, mas também no lado externo do tampão inferior.

Verificou-se, todavia, que por ocasião dos ataques das Lestrimelitta limao, grande número de abelhas sai para atacar as assaltantes e, do fundo da colmeia é transportada uma bola de própolis, com a qual obstruem a entrada; todavia, se esta bola for empurrada pa- ra o interior da galeria, pelo observador, em aproximadamente cinco segundos, é substituída por outra maior, para ser substituida por outra bola de maior diâmetro, num periodo de tempo que varia de dez a quinze segundos, se a segunda bola foi deslocada do lugar; porém, desta vez, soldada às paredes da galeria por gomas e resinas e apertada fortemente. Se a colônia possuir duas entradas, ambas sāo obstruidas simultaneamente. $O$ ruído da queda das bolas no interior, quando empurradas pelo observador, é audível, assim como o transporte ascendente pela galeria, daquelas que substituem a primeira.

Presume-se que os mesmos artefatos, que se observam em colônias de Melipona seminigra merrillae e Melipona crinita, se destinam ao mesmo fim.

A despeito da presença destes artefatos e facilidade de transporte que se tem observado, o súbito ataque em massa das Lestrimelitta limao, descontrola, por vezes, a vigilância e atuação das abelhas guardas das colônias atacadas, levando-as, em Melipona rufiventris, a abandonarem os ninhos, para se refugiarem mais longe e, em Melipona interrupta, a combates em que as colônias atacadas perecem sem que se possam observar lesões graves nas abelhas mortas.

As abelhas das colônias de Melipona rufiventris que sustaram o ataque e permanecem no exterior, dada a obstrução da entrada ou entradas das suas colônias, passaram a atacar as Lestrimelitta limao em um caso em que estas levaram o ataque a colônias vizinhas de Melipona interrupta. Após o anoitecer e fim do assalto, a entrada ou entradas são desobs. truídas $\mathrm{e}$ as abelhas que permaneceram no exterior e se encontram pousadas junto à entrada ou entradas, penetram no interior da colônia.

(Aceito para publicação em 11-03-78) 